\title{
Patterns and processes of larval fish supply to the coral reefs of the upper Florida Keys
}

\author{
Evan D'Alessandro ${ }^{1, *}$, Su Sponaugle ${ }^{1}$, Thomas Lee $^{2}$ \\ ${ }^{1}$ Division of Marine Biology and Fisheries, and ${ }^{2}$ Division of Meteorology and Physical Oceanography, \\ Rosenstiel School of Marine and Atmospheric Science, University of Miami, 4600 Rickenbacker Causeway, Miami, \\ Florida 33149-1098, USA
}

\begin{abstract}
To identify temporal and spatial patterns in the supply of late-stage fish larvae to the coral reefs of the upper Florida Keys, 3 replicate light traps that collect larvae in the process of settling were deployed at each of 2 reefs from May 2002 to February 2004. Traps were deployed every other night from May through October and twice monthly from November through April to examine cross-shelf (2002 and 2003) and alongshore (2002 and 2004) patterns. The nightly abundance of settling larvae was compared to concurrently collected environmental data to assess the relationships between these variables and temporal patterns of larval supply. In total, 26185 fish larvae from 55 families were collected during 174 nights of sampling. Seasonally, the supply of larvae peaked in the late winter to early spring and reached a minimum in late fall. Within-season supply of late-stage larvae was cyclic and strongly related to the lunar cycle, and to a lesser extent, the maximum tidal amplitude cycle. Strong negative correlations between larval supply and both moon illumination and maximum tidal amplitude each night resulted in peak supply of fish larvae between the third quarter moon/minimum amplitude tides and the new moon/maximum amplitude tides. While these cyclic environmental cues provided a high degree of temporal predictability of larval pulses, the magnitude of pulses was stochastic, with some variability related to the passage of mesoscale frontal eddies by the upper Florida Keys. However, the effects of these physical features on larval supply were not consistent over time. Spatial variability (kilometer-scale) was greater in the cross-shelf direction than in the alongshore direction: the supply of larval fishes was significantly greater to the fringing reef site (French Reef) than to the inshore patch reef (White Banks), due to either active larval avoidance of inshore environments or depletion of larvae originating offshore as they pass over and settle on the fringing reef.
\end{abstract}

KEY WORDS: Reef fish $\cdot$ Larval supply $\cdot$ Frontal eddies $\cdot$ Lunar cycle

\section{INTRODUCTION}

For many marine organisms with complex life cycles, identifying the patterns and processes associated with the supply (or delivery) of settlement-stage larvae to benthic juvenile habitats is critical to our understanding of how populations are replenished over time. The entry or recruitment of young coral reef fishes into a population, for example, is typically highly variable (Victor 1986b, Doherty 1991, Sponaugle \& Cowen 1996a, 1997, Robertson \& Kaufmann 1998), frequently due to variability in the supply of larvae (Milicich \&
Doherty 1994, Thorrold et al. 1994, Sponaugle \& Cowen 1996b, Kingsford \& Finn 1997, Lozano \& Zapata 2003). While variation in population replenishment first occurs during reproduction (Robertson et al. 1988, Meekan et al. 1993, Dorsey 2000), highly variable biological (e.g. food availability, predator abundance, larval growth, and behavior) and physical (e.g. wind, storm events, currents, and other oceanographic features) processes of the pelagic larval environment are often sufficient to decouple spatial and temporal patterns of reproduction and supply. In many cases, these processes better explain the variability associated with 
larval reef fish supply and the extent to which larvae are retained or expatriated from source populations (Robertson et al. 1993, Cowen 2002, McIlwain 2002). It is unlikely that either biological or physical factors exclusively control variability in larval supply, and the balance between the 2 likely shifts in different situations, locations, and for different species.

As the only coral reef system in the contiguous United States, the Florida Keys (FK) reef tract is a unique and highly dynamic area that lies between the Florida Current (FC), a major western boundary current which transports water at speeds of up to $200 \mathrm{~cm}$ $\mathrm{s}^{-1}$ (Lee \& Williams 1999), and Hawk Channel, a shallow natural channel running the entire length of the FK and connected to the shallow lagoon of Florida Bay via numerous tidal channels (see Fig. 1). While extensive work on larval fish assemblages has been conducted in the offshore waters of the upper FK and Key Largo (e.g. 'Southeast Florida and Caribbean Recruitment Project', SEFCAR, during the 1980s), few studies have measured the successful delivery of these larvae to the adjacent coral reefs. Assemblages of larval fishes directly over FK reefs are markedly different from offshore assemblages and are highly dynamic over time, even in the absence of FC associated flow variability (Sponaugle et al. 2003). Elsewhere, larvae frequently settle on a cyclical basis correlated with lunar/tidal amplitude cycles, with supply peaking on the new moon (Victor 1986b, Robertson 1992, Thorrold et al. 1994, Sponaugle \& Cowen 1996b, 1997, Robertson et al. 1999, Wilson 2001) or third quarter moon (Sponaugle \& Cowen 1996b, 1997). No long-term time series records of larval fish supply are available for the FK, thus little is known regarding seasonal or monthly patterns of supply. Recently, evidence has demonstrated that mesoscale eddies propagating along the FC frontal boundary can increase the nearshore occurrence of spiny lobster and penaeoid shrimp larvae in the lower FK (Criales \& Lee 1995, Yeung \& Lee 2002) and deliver late-stage fish larvae to reefs of the upper FK (Sponaugle et al. 2005). However, the frequency and ubiquity of the effects of these transport features on larval fish supply to FK reefs is unknown. This study was undertaken to measure temporal and spatial patterns of larval fish supply to the reefs of the upper FK year-round, and to identify the relative role of cyclic and episodic environmental influences on this supply.

\section{MATERIALS AND METHODS}

Study area. The prevailing water flow of the FC along the seaward side of the FK and its coral reefs is greatly influenced by the shape and curvature of the continental shelf from an E-W orientation in the lower Keys to a N-S orientation off the upper Keys (Fig. 1).

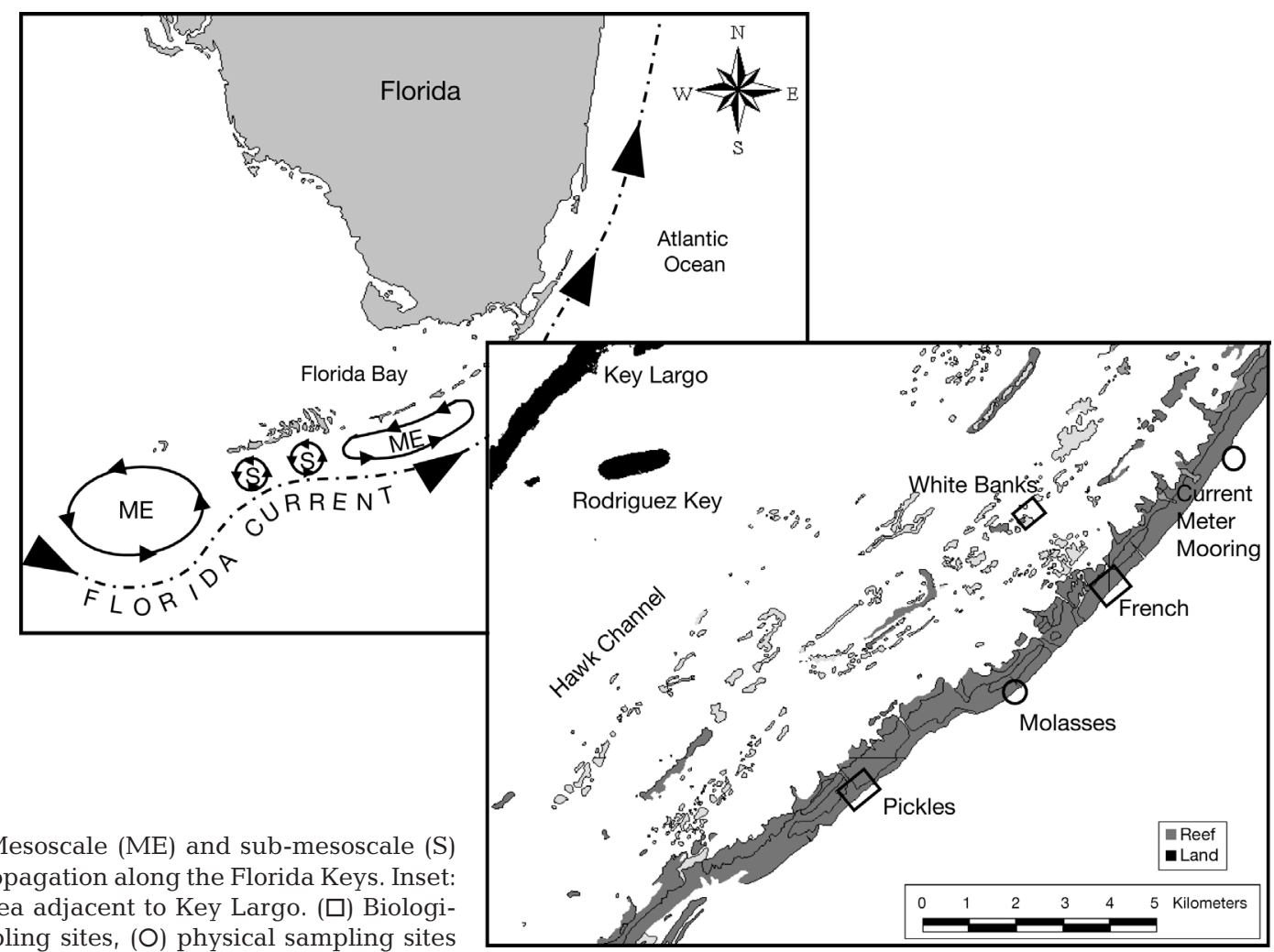

Fig. 1. Mesoscale (ME) and sub-mesoscale (S) eddy propagation along the Florida Keys. Inset: study area adjacent to Key Largo. ( $\square$ ) Biological sampling sites, (O) physical sampling sites 
Offshore of the FK, shallow (3 m) nearshore bathymetry gradually gives way to Hawk Channel, which lies approximately $3 \mathrm{~km}$ offshore and may be as deep as $10 \mathrm{~m}$. This natural feature is enclosed on the seaward side ( $6 \mathrm{~km}$ offshore) by numerous patch reefs and eventually the bank reef ( 10 km offshore), which breaks the surface at low tide in many locations. Beyond the bank reef the continental shelf drops to a break at approximately $30 \mathrm{~m}$, where the shelf edge plummets hundreds of meters into the Straits of Florida (SOF; Pitts 1994, Lee \& Williams 1999).

Current flow landward of the fringing reefs and along the entire FK is influenced by seasonally varying wind and tidal cycles. Although cross-shelf flow over the outer shelf and bank reef is largely tidally driven (Lee 1986), alongshore currents are dominated by the FC and its associated transient eddies and meanders. However, the relative importance of these processes varies within the FK. The offshore waters of the lower Keys are an example of an eddy-dominated system (Lee \& Williams 1999). Mesoscale eddies (ME; previously referred to as Tortugas gyres) occur on a 30 to $60 \mathrm{~d}$ time scale offshore of the Dry Tortugas due to southwardpropagating eddies on the eastern side of the Loop Current in the Gulf of Mexico (see Fig. 1). These cold-core, counter-clockwise rotating eddies exist on a spatial scale of approximately $100 \mathrm{~km}$ cross-shelf and $180 \mathrm{~km}$ along-shelf, and tend to stall at the entrance to the $\mathrm{SOF}$, where they can reside for several weeks to months until they move eastward into the SOF at about 5 to $10 \mathrm{~km}$ $\mathrm{d}^{-1}$. As they propagate past the middle and upper FK, the MEs elongate alongshore, are sometimes sheared apart, and accelerate in alongshore translation to approximately 3 times their speed in the western SOF (Lee et al. 1992, 1994, 1995, Fratantoni et al. 1998; Fig. 1). Due to this acceleration and elongation, MEs affect any given point along the upper FK on a time scale of several weeks. High frontal shear of the FC downstream velocity can cause sub-mesoscale frontal eddies (SME) to form anywhere along the western FC front. In contrast to MEs, these smaller eddies exist on a temporal scale of $2 \mathrm{~d}$ to $2 \mathrm{wk}$ and on a spatial scale of 10 to $20 \mathrm{~km}$ cross-shelf and 2 to 3 times this length alongshore. Both MEs and SMEs can result in alongshore current reversals along the outer shelf and have been implicated in the cross-shelf transport of fish and invertebrate larvae (Criales \& Lee 1995, Limouzy-Paris et al. 1997, Yeung \& Lee 2002, Sponaugle et al. 2005).

In summer months when stratification of the water column is at its greatest, internal tidal bores are a common feature of the shelf slope in the FK. These features can act as subsurface cross-shelf transport mechanisms, increasing the near-bottom abundance of zooplankton and some larval fish on the reef slope on hourly time scales (Leichter et al. 1996, 1998).
Biological sampling. Biological sampling was conducted at 3 coral reefs inside the Florida Keys National Marine Sanctuary (FKNMS) offshore of Key Largo, Florida. Two of the sites, French Reef (FR) and Pickles Reef (PI), are part of the bank reef tract and are located $\sim 10 \mathrm{~km}$ offshore and separated $\sim 7 \mathrm{~km}$ alongshore (Fig. 1). The third site, White Banks (WB), is an inshore patch reef located $\sim 2 \mathrm{~km}$ NW of FR, inside Hawk Channel. These sites were selected due to their accessibility and recent use in ongoing studies of near-reef larval fish assemblages and recruitment (Sponaugle et al. 2003, 2005).

In order to examine temporal patterns of larval fish supply, 3 replicate light traps were deployed every other night at FR for two 6 mo 'summer' periods (May to October), and twice a month for two 6 mo 'winter' periods (November to April). Traps were deployed in the winter only during third quarter and new moon phases because the longer record of near-continuous summer sampling indicated that these were peak larval supply periods (see 'Results'). In order to examine cross-shelf and alongshore spatial patterns of larval fish supply on a scale of kilometers, 3 replicate samples were concurrently collected at WB (June 2002 to April 2003) and PI (May 2003 to February 2004). Although it was not logistically possible to sample more than 2 sites each night, sampling repeatedly through time helped to offset this limitation. Adverse sea conditions or equipment malfunction resulted in two $7 \mathrm{~d}$ (20 to 27 May; 27 May to 3 June) and two 5 d (10 to 15 August; 27 September to 2 October) sampling gaps in 2002, as well as one $6 \mathrm{~d}$ ( 1 to 7 May) and one $8 \mathrm{~d}$ gap (21 to 29 July) in 2003.

Light traps were utilized to intercept late-stage fish larvae as they approached the reef to settle. Late-stage fish larvae that are ready or near-ready to settle are agile and poorly sampled by other means, such as towed nets (Choat et al. 1993, Meekan et al. 2001). Although light trap sampling of phototaxic larvae may lead to taxonomic bias and a low sampling efficiency, it is a useful method and an effective means of measuring relative larval supply (Doherty 1987, Meekan et al. 2000). Traps were modified from a design by Sponaugle \& Cowen (1996a) and consisted of a cylinder of Nitex netting with 3 funnel-shaped openings surrounding a submersible 6 inch $(15.24 \mathrm{~cm}) 6 \mathrm{~W}$ fluorescent light. Similar light traps have been used to sample larval fishes and invertebrates in Barbados and St. Lucia (Sponaugle \& Cowen 1996b, Reyns \& Sponaugle 1999, Valles et al. 2001) and previously in the FK (Sponaugle et al. 2005). Traps were fixed to FKNMS moorings, located approximately $50 \mathrm{~m}$ seaward of the reef crest in 3 to $10 \mathrm{~m}$ of water. Trap deployment occurred at sunset, and retrieval at dawn of the following day. Although some settlement may take place 
during the day (Leis \& Carson-Ewart 1999), the majority of settlement in reef fishes is thought to occur at night (Victor 1986a, Robertson et al. 1988, Dufour \& Galzin 1993). Samples were preserved in $95 \%$ ethanol immediately upon collection.

Larval fishes were removed from samples, counted, and identified to the most specific taxonomic level possible using early drafts of Richards (2006). Larvae were further classified as competent or non-competent to settle. Due to the paucity of literature on the size at which many reef fish are competent to settle and the difficulty in defining competency criteria (McCormick 1999), individuals were considered to be non-competent if they were pre-flexion or markedly small and underdeveloped compared to other individuals of the same taxon. For the purpose of this study, only latestage larvae of each taxon were analyzed.

Physical sampling. Water temperature and current velocity data were recorded by two Sontek ArgonautMD acoustic Doppler current meters fixed to a single subsurface mooring at 4 and $21 \mathrm{~m}$ depths. The mooring was located at $25^{\circ} 04^{\prime} \mathrm{N}, 80^{\circ} 19^{\prime} \mathrm{W}$ near the shelf break (26.8 $\mathrm{m}$ depth; Fig. 1). Data were recorded every $5 \mathrm{~min}$ from 4 April 2002 to 10 October 2002 and from 12 May 2003 to 20 October 2003. Daily and weekly composite, $1 \mathrm{~km}$ resolution, ocean color satellite imagery of the region was provided by the University of South Florida's Institute for Marine Remote Sensing (IMaRS). Data on wind velocity were obtained from the NOAANDBC SEAKEYS/C-MAN station MLRF1 located at Molasses Reef $\left(25^{\circ} 01^{\prime} \mathrm{N}, 80^{\circ} 38^{\prime} \mathrm{W}\right.$; Fig. 1). These data were recorded every $10 \mathrm{~min}$ and were available for the entire 2 yr period. Tidal height and amplitude data were obtained from the University of South Carolina's online tide and current predictor, and data on moonrise/moonset and percent of the moon illuminated each night were obtained from the Astronomical Application Department of the US Naval Observatory.

Raw data. The number of fish larvae collected at a given site each night was averaged across the 3 replicate traps to obtain the mean nightly larval supply. In the event that 1 or 2 traps failed due to a light or trap malfunction, the mean nightly catch was estimated from the remaining trap or traps. Prior to analyses, all mean nightly catch data were $\ln (x+1)$-transformed to stabilize the variance caused by large, rare peaks. Data were then smoothed using a 3-point moving average and missing values were estimated using nonlinear interpolation.

Catches were usually dominated by larvae of the families Atherinidae, Clupeidae, and Engraulidae (ACE complex; see 'Results'). Because these fishes do not recruit to the benthos but instead remain in nearshore surface waters throughout their life history, for the purposes of this study, they were omitted from statistical analysis (Sponaugle \& Cowen 1996b). Individual fish taxa from the remaining data were analyzed separately if they appeared in the traps on at least 5 occasions and at least 20 individuals were captured at a given reef per year.

Physical data on wind and current velocity were first separated into cross-shelf (u) and alongshore (v) components and then rotated $40^{\circ}$ clockwise from true north (positive toward $40^{\circ}$ alongshore and $130^{\circ}$ cross-shelf) to comply with oceanographic convention in this region. These data were then filtered with a $40 \mathrm{~h}$ Butterworth filter to remove variability on tidal time scales (Roberts \& Roberts 1978). To investigate the influence of the FC on currents, the effect of the wind was removed by subtracting the results of a linear regression between wind and currents (Sponaugle et al. 2005). Average nightly current and wind velocities were calculated by averaging the 5 min current velocity and $10 \mathrm{~min}$ wind velocity data from 20:00 to 06:00 $\mathrm{h}$ for each night during the sampling seasons. Nightly and half-nightly hours of moonlit and dark rising and falling tides were calculated by combining sunrise/sunset, moonrise/moonset, and percent illumination of the moon with nightly tidal height data.

Data analysis. Cyclic temporal patterns: Seasonal cycling in the supply of larvae was investigated by examining plots of monthly larval supply to FR over the entire 2 yr study period. Monthly values of larval supply were calculated by averaging supply from the nights of the third quarter and new moon for each calendar month as these were sampled in all months throughout the study. New and third quarter moon periods were defined as the average of all available larval fish catches from the night before, night of, and night after each new and third quarter moon. Data were examined for all late-stage larvae together and family richness (mean number of fish families collected each night). Data were also examined for individual taxa that occurred most frequently during new and third quarter moons (indicated by Rayleigh statistics) and whose average nightly supply during third quarter and new moon periods summed over the entire study exceeded 20.

Within-season monthly patterns of nightly larval supply were examined for the two 6 mo nearcontinuous sampling periods (May to October) at FR because this site was sampled over both years. In order to examine cycling in the supply of larvae, the autocorrelation function $(\mathrm{ACF})$, which identifies cycling within a data set, was applied to the mean number of settlement-stage fish larvae and mean number of fish families collected each night (Batschelet 1981). This test indicated that the relative abundance of settlement-stage larvae and family richness cycled at a period of approximately 29 d in both 2002 and 2003. 
These data were therefore examined relative to the environmental parameters of moon phase and maximum tidal amplitude, which cycle at a similar period.

The raw nightly catch data were summed across traps for each night and assigned a lunar day (Day 1 corresponding to the new moon; Day 15 corresponding to the full moon) and tidal amplitude day (Day 1 corresponding to the maximum amplitude tide closest to the new moon). These data were collapsed into a single lunar and tidal amplitude cycle, standardized to the mean number of larvae captured per lunar/tidal day, and plotted over a single lunar/tidal amplitude cycle. Rayleigh tests were employed to determine if the standardized catches of larval fish were uniformly distributed about the lunar/tidal amplitude cycles (Zar 1999). When data were non-randomly distributed, the mean lunar or tidal day about which the data were centered was calculated. Where data were bimodally distributed over the lunar/tidal amplitude cycle, the lunar/ tidal amplitude cycle was split and a Rayleigh test applied to each half separately (Zar 1999).

Because behavior may be cued by a combination or hierarchy of variables (Morgan \& Christy 1994), crosscorrelation functions (CCF) were carried out between nightly hours of moonless and moonlit flood and ebb tides and larval supply (SYSTAT 11). Correlations where environmental events preceded catches of larvae by $>6$ d were considered unreliable, and negative lags between larval supply and physical variables were ignored, as these indicated that peaks in catches preceded environmental events (Kingsford \& Finn 1997). In addition, because of the increased probability of committing a Type II error associated with repeatedly performing a statistical test, correlation coefficients that were within the $95 \%$ confidence interval and between -0.3 and 0.3 were considered to be only weakly significant. In order to further refine results where correlations were strong, nightly hours of environmental cycles were split into half-nightly intervals (sunset-midnight and midnight-sunrise; many fish larvae are thought to settle during the first half of the night) and CCFs were recalculated.

Non-cyclic variability: The larval supply data were examined for possible correlations with non-cyclic environmental parameters such as average nightly wind and current velocity as well as transient hydrographic features, such as passing frontal eddies and internal tidal bores. Prior to these analyses, significant cycling in the biological data was removed since such periodicity would increase the probability of committing a Type I error. To do so, the generalized linear model (GLM) function in SYSTAT 11 was used to estimate a model of larval abundance due to the percent of the moon illuminated and maximum tidal amplitude (variables with which cyclic patterns of supply were most correlated; see 'Results'). The residuals of this model were examined (via ACF plot) to ensure that all significant periodicity had been removed, and then were compared (through CCFs) to non-cyclic environmental parameters such as the $\mathrm{u}$ and $\mathrm{v}$ component of average nightly currents and wind velocity, ME passage, and internal tidal bore frequency.

Periods when MEs and SMEs passed by the study area were identified by examining the current meter and water temperature records, as well as ocean color satellite imagery. The leading edge of a ME is characterized by a drop in near-bottom water temperature, strong onshore surface flow, and northeasterly (downstream) flow caused by the onshore position of the FC front within the leading onshore meander (Lee 1975, Lee et al. 1994, 1995). As the eddy passes, near-bottom temperature increases, accompanied by a weakening or reversal of the NE alongshore current. Immediately following the eddy's passage, the FC meanders towards shore again, causing strong NE alongshore flow and an accompanied drop in near-bottom temperature (Lee et al. 1992, 1994, Lee \& Williams 1999, Sponaugle et al. 2005). Alongshore and cross-shelf dimensions of frontal eddies were approximated from satellite imagery, and those $>50 \mathrm{~km}$ alongshore were considered to be MEs. The presence of internal tidal bores was identified using the high-frequency, $10 \mathrm{~min}$, unfiltered near-bottom water temperature data, as internal tidal bores deliver cold, nutrient-rich water resulting in large, high-frequency, semidiurnal drops in temperature and accompanying onshore flow.

Spatial patterns: The overall mean abundance of larval fish was compared between concurrently collected samples from FR and WB in 2002 to examine cross-shelf differences, and FR and PI in 2003 to examine alongshore differences in the magnitude of larval supply between sites. Due to heteroscedasticity and non-independent errors, non-parametric Mann-Whitney $U$-tests were employed to compare the overall magnitude of larval supply under the null hypothesis of no significant difference between sites (Zar 1999). Temporal patterns of larval supply were compared among sites using cross-correlation techniques.

\section{RESULTS}

\section{Taxonomic composition of larval fish collections}

In total, 26185 fish larvae from 55 families were collected in the light traps during this study. Overall mean nightly abundance values ranged from zero to nearly 200, and the average mean nightly abundance was approximately 14 larvae. Excluding fishes of the ACE complex, the catches were dominated by damselfishes 
Table 1. Rayleigh statistics for family and taxon-specific patterns of larval fish supply over lunar and tidal amplitude cycles. Data analyzed from near-continuous nightly sampling for two 6 mo periods (May to October 2002 and 2003) at French Reef (FR), Florida Keys. $\mathrm{n}$ overall = total number of individuals caught at all sites for duration of study; $\%$ total = percent of overall catch composition (Atherinidae, Cluperidae, Engraulidae complex excluded) represented by relevant family; $\mathrm{n}(\mathrm{mean})=$ number of individuals caught at FR standardized to 1 sample per lunar or tidal day; $Z=$ Rayleigh test statistic (Zar 1999); Day = mean lunar or tidal day about which data are centered. All $Z$-values are significant at $\mathrm{p}<0.001$, except where denoted by ${ }^{*}(\mathrm{p}<0.05)$, or ns (not significant). In the case of Stegastes partitus, which had a bimodal distribution, the test was performed for the first half

(Days 1 to 15) and second half (Days 16 to 30) of the lunar or tidal cycle separately

\begin{tabular}{|c|c|c|c|c|c|c|c|c|}
\hline \multirow{2}{*}{ Family, species, or type } & \multirow{2}{*}{$\begin{array}{c}\mathrm{n} \\
\text { overall }\end{array}$} & \multirow{2}{*}{$\begin{array}{c}\% \\
\text { total }\end{array}$} & \multicolumn{3}{|c|}{ Lunar cycle } & \multicolumn{3}{|c|}{ Tidal amplitude cycle } \\
\hline & & & $\mathrm{n}$ (mean) & Z & Day & $\mathrm{n}(\mathrm{mean})$ & Z & Day \\
\hline Apogonidae & 83 & 0.7 & 10.86 & 4.14 & 28.7 & 11.41 & ns & \\
\hline Blennidae & 422 & 3.4 & 11.91 & ns & & 16.51 & $\mathrm{~ns}$ & \\
\hline Carangidae & 99 & 0.8 & 8.97 & ns & & 9.42 & ns & \\
\hline Chaenopsidae & 749 & 6.1 & 35.64 & 19.20 & 28.3 & 39.35 & 14.46 & 27.6 \\
\hline Gerreidae & 632 & 5.1 & 63.46 & 23.28 & 27.6 & 80.21 & 28.43 & 27.0 \\
\hline Gobiidae (Ioglossus sp.) & 105 & 0.9 & 11.07 & $\mathrm{~ns}$ & & 9.21 & ns & \\
\hline Haemulidae & 86 & 0.7 & 8.03 & $2.82^{*}$ & 29.1 & 8.40 & $3.06^{*}$ & 28.8 \\
\hline Holocentridae & 66 & 0.5 & 14.24 & 4.58 & 4.6 & 13.22 & 5.28 & 1.2 \\
\hline Labridae (Doratonotus megalepis) & 206 & 1.7 & 14.51 & 6.36 & 26.1 & 14.69 & 6.16 & 24.6 \\
\hline Labrisomidae (Type A) & 312 & 2.5 & 34.21 & 20.36 & 25.1 & 39.67 & 26.39 & 23.9 \\
\hline Labrisomidae (Type D) & 70 & 0.6 & 9.88 & 4.59 & 27.9 & 9.68 & 4.79 & 26.7 \\
\hline Lutjanidae (Lutjanus griseus) & 78 & 0.6 & 9.39 & 5.01 & 22.5 & 10.52 & 6.13 & 21.1 \\
\hline Lutjanidae (Type B) & 52 & 0.4 & 9.14 & 3.57 & 26.7 & 8.46 & 3.53 & 25.3 \\
\hline Monacanthidae & 160 & 1.3 & 25.30 & 10.33 & 29.8 & 27.88 & 14.11 & 29.3 \\
\hline Opistognathidae (Type A) & 425 & 3.5 & 61.76 & 20.50 & 27.2 & 66.98 & 28.43 & 26.1 \\
\hline \multirow[t]{2}{*}{ Pomacentridae (Stegastes partitus) } & 961 & 7.8 & 73.67 & 43.04 & 5.6 & 72.10 & 49.88 & $6.0^{\circ}$ \\
\hline & & & 72.20 & 46.31 & $23.6^{\mathrm{a}}$ & 100.00 & 39.72 & 24.5 \\
\hline Scaridae (Sparisoma spp.) & 385 & 3.2 & 31.73 & $3.27^{*}$ & 0.9 & 31.53 & 4.15 & 0.1 \\
\hline Scombridae & 110 & 0.9 & 15.63 & 5.62 & 2.2 & 15.35 & 6.10 & 1.2 \\
\hline Scorpaenidae (Type A) & 152 & 1.2 & 26.89 & 13.90 & 0.6 & 29.80 & 15.33 & 29.8 \\
\hline Scorpaenidae (Type B) & 156 & 1.3 & 14.21 & 5.23 & 27.8 & 14.45 & 4.42 & 26.5 \\
\hline Sphyraenidae & 142 & 1.2 & 25.31 & 9.97 & 27.8 & 29.04 & 12.19 & 27.5 \\
\hline Tripterygiidae & 719 & 5.9 & 66.61 & 27.98 & 29.0 & 67.75 & 29.84 & 28.1 \\
\hline All late-stage larvae & 9737 & 79.3 & 961.77 & 237.84 & 28.0 & 1021.76 & 246.16 & 27.7 \\
\hline Family richness & & & 298.89 & 27.53 & 29.2 & 310.23 & 32.84 & 28.9 \\
\hline
\end{tabular}

(Pomacentridae), tube blennies (Chaenopsidae), triplefin blennies (Tripterygiidae), mojarras (Gerreidae), lanternfishes (Myctophidae), porgies (Sparidae), labrisomids (Labrisomidae), jawfishes (Opistognathidae), and parrotfishes (Scaridae). These 9 families comprised approximately half of the non-ACE fish larvae captured (Table 1). Besides benthic reef-associated fishes, collected families included fishes associated with seagrass and mangroves as juveniles or adults, such as grunts (Haemulidae), mojarras, barracudas (Sphyraenidae), snappers (Lutjanidae), and razorfishes (Labridae, Xyrichtys spp.); mid-water reef-associated fishes such as jacks (Carangidae); pelagics such as tunas and mackerels (Scombridae), billfishes (Istiophoridae), and snake mackerels (Gempylidae); shelf-slope fishes such as codlets (Bregmacerotidae); and mesopelagics such as bristlemouths (Gonostomatidae) and lanternfish. Because of the relative scarcity of many families collected, only 22 taxa from 19 families were analyzed separately. Although a diversity of larvae were captured, it is evident from a previous study in this area which utilized net tows to sample ichthyoplankton, that certain taxa were undersampled or absent from light trap samples due to gear bias (i.e. Thalassoma bifasciatum and the families Exocoetidae, Balistidae, Eleotridae, and Callionymidae; Sponaugle et al. 2003).

\section{Seasonal patterns of larval supply}

Mean monthly supply of all late-stage fish larvae to FR was highest in spring and early summer, and decreased in fall and early winter (Fig. 2A). A similar, although less distinct, pattern was evident in family richness (Fig. 2B). Seasonal patterns for individual taxa were more difficult to discern due to numerous zero values. The 15 taxa which occurred most frequently and in greatest numbers during new and third quarter moon periods throughout the year, fell into 2 main patterns. Scarids of the genus Sparisoma (Fig. 2C), the pygmy wrasse Doratonotus megalepis, the pinfish Lagodon rhomboides, scorpaenids (Type B), blennies 

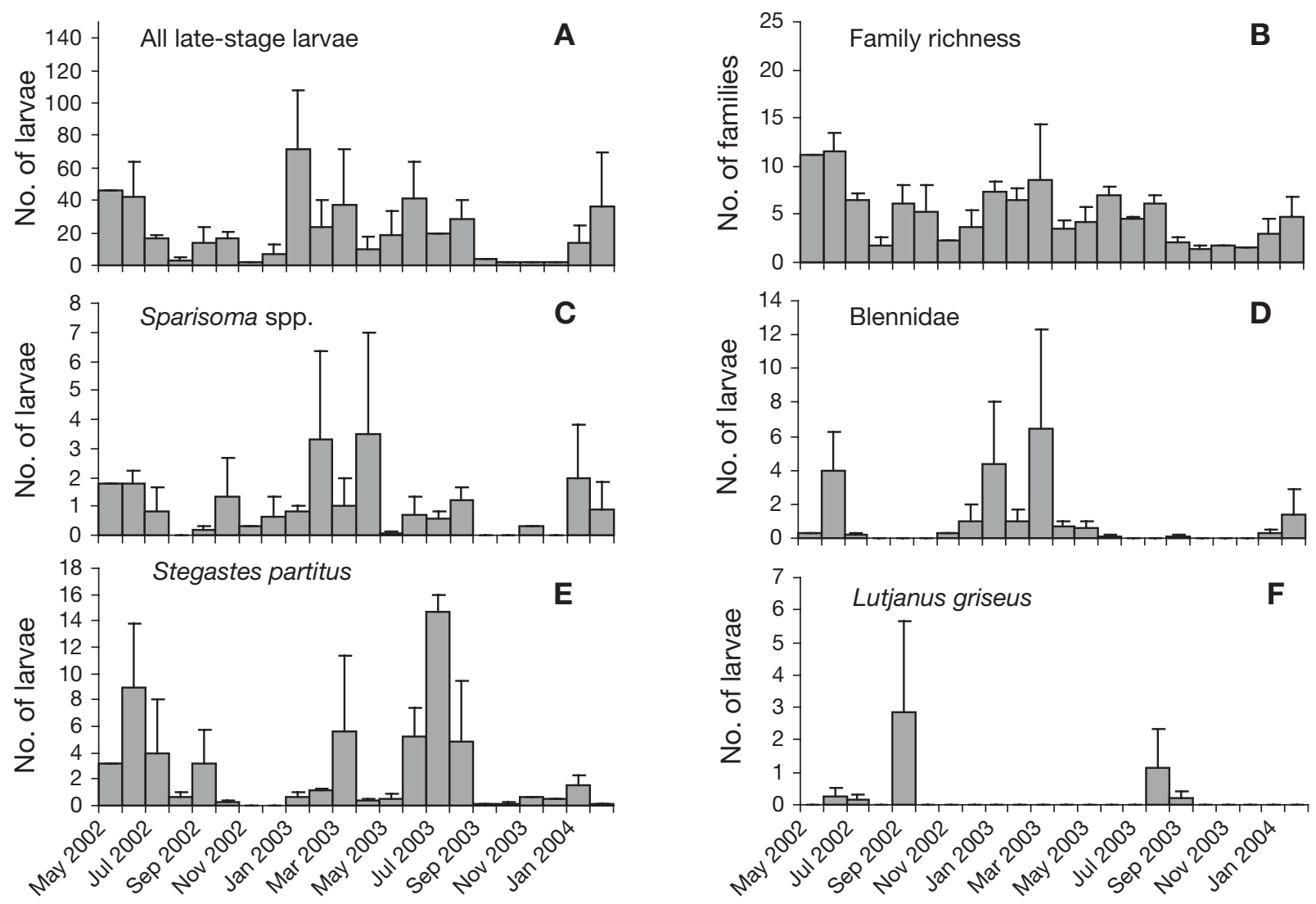

Fig. 2. Two year monthly averages of all late-stage fish larvae, family richness, and several individual taxa at French Reef. All months were sampled; thus no values indicate zeros. Error bars represent SE. Monthly values with no error bars indicate that only third quarter or new moon was sampled for that month

(Blennidae; Fig. 2D), opistognathids (Type A), and tripterygiids all exhibited a pattern similar to all latestage larvae together, peaking in abundance in late winter-early spring and tapering to a minimum in late fall. Pomacentrids (Type A and Stegastes partitus; Fig. 2E), sphyraenids, filefishes (Monacanthidae), lutjanids (Lutjanus griseus; Fig. 2F), labrisomids (Type A), scorpaenids (Type A), and gerreids appeared in greatest numbers in the summer and were scarce or absent in the late fall-early spring.

\section{Within-season lunar and tidal periodicity}

The lunar and maximum tidal amplitude cycles are closely coupled in the FK. Maximum tidal amplitude in the FK ranges from $0.5 \mathrm{~m}$ during first and third quarter moons to $1 \mathrm{~m}$ during new and full moons (Fig. 3). All larvae together, family richness, and most individual taxa analyzed were non-randomly distributed over the lunar and tidal amplitude cycles, peaking between Days 21 and 30 (third quarter moon/minimum amplitude tides and new moon/maximum amplitude tides, respectively; Table 1, Fig. 4). Exceptions were the scombrids, scorpaenids (Type A), and scarids (Sparisoma spp.), which occurred in greatest numbers just after the new moon/maximum amplitude tides, and squirrelfishes (Holocentridae), which pulsed between the new moon/maximum amplitude tides and the first quarter moon/minimum amplitude tides (Table 1). Distributions of the 4 most abundant taxa as well as all fish larvae together and family richness plotted over a single lunar and tidal amplitude cycle revealed that most taxa were caught in very low numbers or not at all for several days around the full moon/maximum amplitude tides (Day 15; Fig. 4).

Hours of moonlit rising and falling tides peak around the full moon, while hours of moonless rising and falling tides peak around the new moon (Fig. 5). Splitting moonless nocturnal hours as well as hours of moonless falling tides into half-nightly increments (tidal amplitude and percent lunar illumination were not split because these parameters remain approximately equal throughout the course of a night) revealed that both parameters peak between the third quarter and new moons in the first half of the night and between the new and first quarter moons in the second half of the night. 

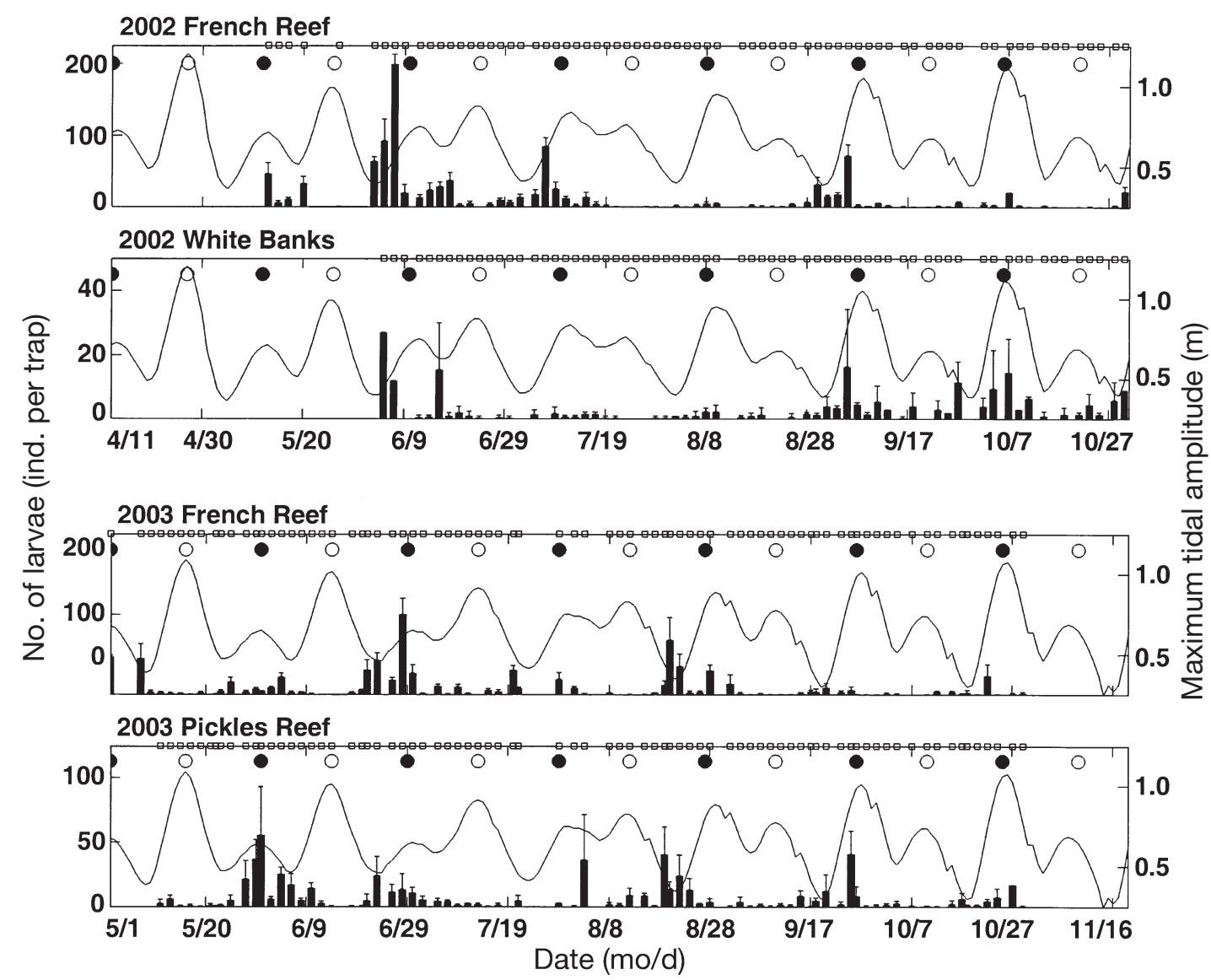

Fig. 3. Mean nightly larval supply at French Reef and White Banks Reef in 2002 and French Reef and Pickles Reef in 2003 (bars), and maximum tidal amplitude (line). (O) Full moon, (@) new moon, ( $\square$ ) nights sampled. For presentation purposes, lunar phases were aligned according to tidal amplitude cycle. Error bars represent SE

The strongest correlation between larval supply and lunar and tidal amplitude cycles was between the percent lunar illumination and larval supply $(-0.70$ at lag of zero; Table 2a). The supply of larvae was positively correlated with hours of complete darkness and hours of dark falling tides, and negatively related to hours of moonlight and hours of moonlit falling tides, and maximum amplitude tides (Table 2a). Although correlations between larval supply and moonlit/moonless nocturnal hours and hours of moonlit/moonless falling tides were not significantly improved when nights were split, correlations tended to be stronger between larval supply and cyclic environmental cues in the first half of the night (Table $2 \mathrm{~b}$ ).

\section{Stochastic physical processes}

Wind and currents

Although highly variable, wind was predominantly from the SE throughout both field seasons and rarely exceeded $10 \mathrm{~m} \mathrm{~s}^{-1}\left(36 \mathrm{~km} \mathrm{~h}^{-1}\right)$. Correlations between nightly larval supply and wind were generally weak and occurred at long lag periods (Table 2c). The filtered current meter data from 2002 and 2003 indicated that there was a substantial amount of semidiurnal variability ( $90 \%)$ in cross-shelf and, to a lesser extent alongshore ( $\sim 50 \%)$ flow on the outer shelf due to tides. Although the adjacent FC predominantly flows to the $\mathrm{N}-\mathrm{NE}$ in this area (positive v component), there were frequent current reversals in both the $u$ and $v$ components (Fig. 6). Removing the effect of wind from the current meter record revealed that wind had a very small effect on currents during May to October of both years, and $\sim 90 \%$ of current variability was due to FC fluctuations. Magnitude of the alongshore current speed was generally greater than that of the crossshelf speed and remained closely coupled at 4 and $21 \mathrm{~m}$ depths. The $\mathrm{u}$ component, however, was frequently out of phase between the 2 depths. No meaningful correlations were identified between residuals of nightly larval supply to FR and the average nightly water flow (Table 2c). 

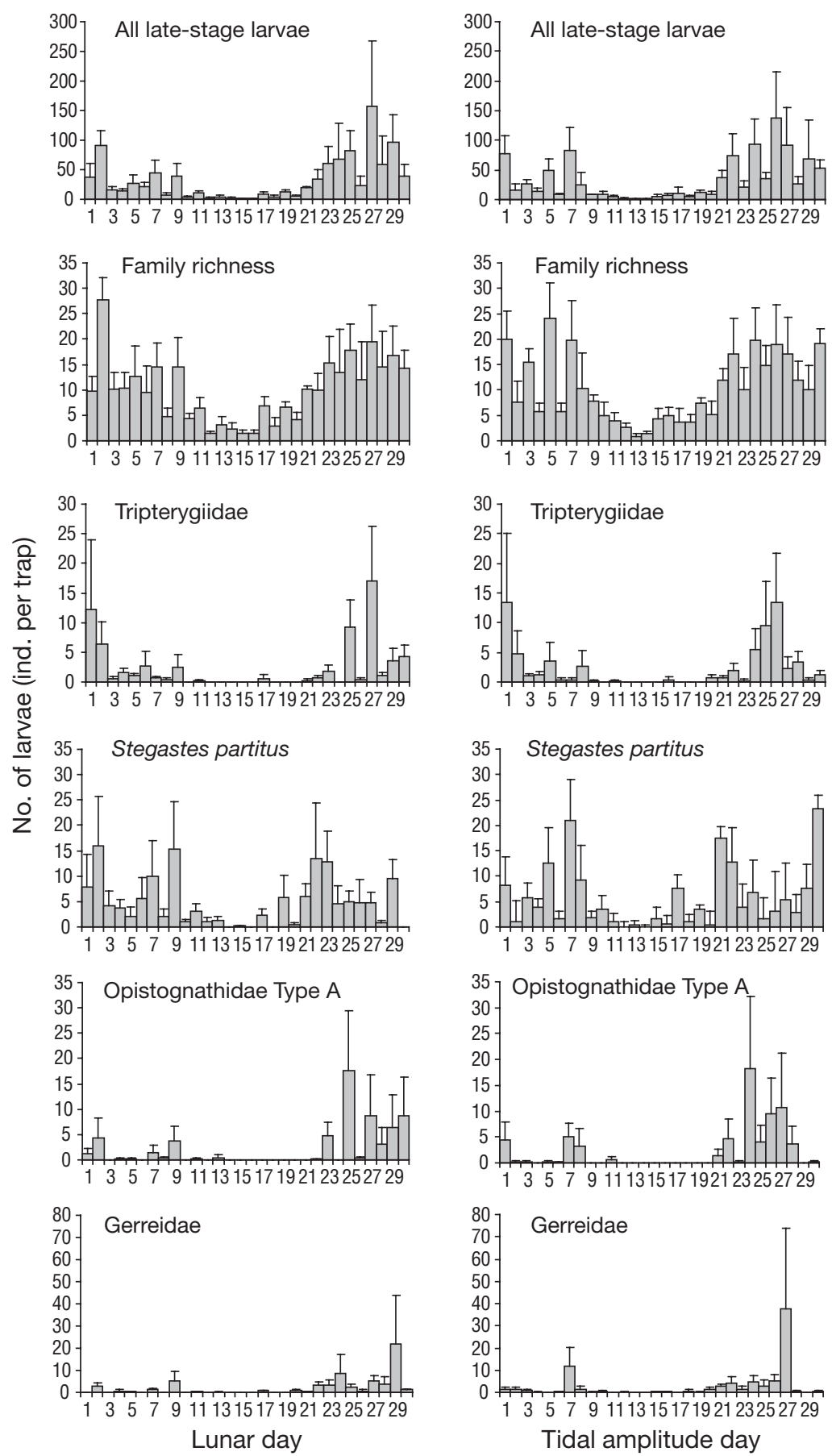

Fig. 4. Mean catches of larval fishes at French Reef during 2002 and 2003 semicontinuous sampling periods (May to October) plotted over single lunar (left column) and tidal amplitude (right column) cycle. Error bars represent SE

\section{Eddies and internal tidal bores}

Satellite imagery and current meter records together indicated that MEs were moving through the study area during the periods of 21 May to 4 June 2002 (ME 1); 15 to 30 July 2002 (ME 2); 18 September to 4 October 2002 (ME 3); 26 June to 20 July 2003 (ME 4); 21 August to 5 September 2003 (ME 5); and 29 September to 8 October 2003 (ME 6; Fig. 6). These periods were superimposed onto plots of observed and expected (based on lunar illumination) larval supply at FR to examine the relationship between frontal eddies and larval supply unexplained by lunar illumination (Fig. 6). While greater than expected larval supply occurred at the end of ME 1 and at the onset of MEs 4 and 5, larval supply was lower than expected during and following $\mathrm{ME} 2$ passage. Several SMEs, independent of MEs, were evident in the current meter records and were characterized by short ( 2 to $4 \mathrm{~d}$ ), sometimes intense, alongshore current reversals. Although these features were numerous, none was associated with enhanced larval fish supply.

Internal tidal bores moved past the $21 \mathrm{~m}$ isobath on the seaward reef slope, characterized by semidiurnal fluctuations of 2 to $5^{\circ} \mathrm{C}$ in the high-frequency unfiltered temperature record. While moderate tidal bore activity was evident for much of the field seasons, the most intense periods occurred from mid to late July and mid September in both 2002 and 2003, during periods of strong downstream baroclinic flow caused by meander crests associated with the leading and lagging edges of mesoscale and sub-mesoscale eddies (Fig. 6c).

\section{Spatial patterns of larval supply}

The overall magnitudes of larval fish supply and family richness were not significantly different between the 2 bank reef sites either in terms of monthly averages over the whole year or nightly averages during May to October 2003 (Table 3a). In contrast, the overall magnitudes of larval fish supply and family richness during May to October 2002 were significantly greater at FR than inshore at WB. However, when only monthly averages (from year-round twice-monthly samples) were compared, there was no significant difference between FR and WB (Table 3b), due to larger catches at WB in the fall (Fig. 3).

Within-season temporal patterns of larval supply between WB and FR as well as PI and FR were gener- 


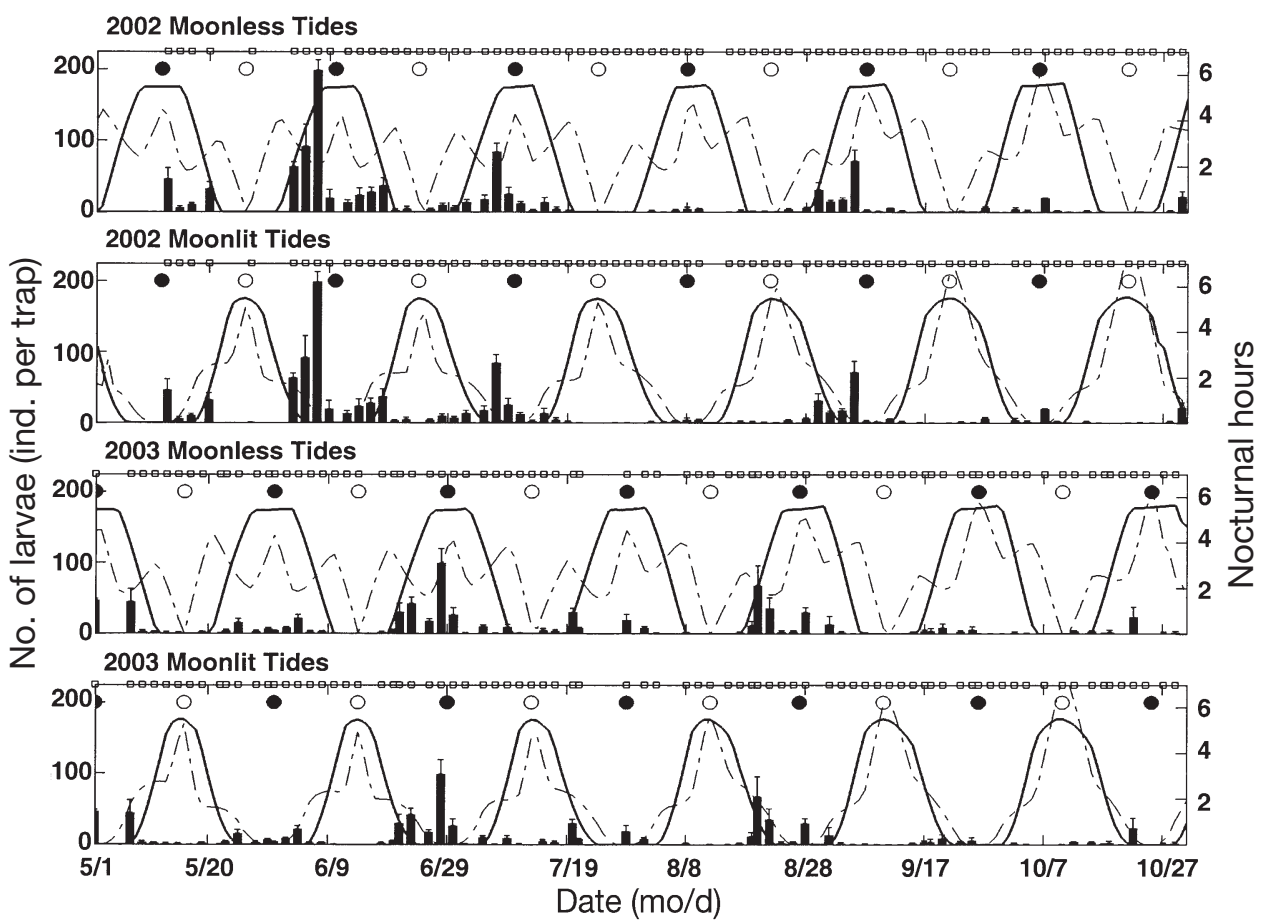

Fig. 5. Hours of moonlit and moonless rising (dashed lines) and falling (continuous lines) tides superimposed on mean larval supply (bars) from May through October 2002 and 2003. (O) Full moon, (๑) new moon, ( $\square$ ) nights sampled.

Error bars represent SE

ally in agreement, although some pulses were better represented at one or other of the sites (Fig. 3). Rayleigh statistics of all late-stage larvae, family richness, and individual taxa were similar between paired sites. Cross-correlations between patterns of larval supply, nightly and half-nightly cyclic environmental processes, tidal cycles, and wind and currents were also generally similar between sites (Table 2).

\section{DISCUSSION}

The supply of late-stage fish larvae to reefs of the upper FK varied at several temporal and spatial scales during the course of this study. Temporal variability in larval fish supply had 3 main components: (1) an interannual seasonal pattern, (2) a within-season cyclic pattern, and (3) stochastic within-season variability. At a scale of kilometers, spatial variability in larval supply was more evident cross-shelf than alongshore. The supply of fish larvae to the study area was largely lunar-cyclic, but the magnitude of this cycle was frequently interrupted by transient oceanic features.
Table 2. Cross-correlations between mean nightly larval supply and (a) light/ dark and rising/falling tidal cycles, (b) significant lunar/tidal parameters split between first and second halves of the night, and (c) average nightly currents and wind. FR $=$ French Reef, $\mathrm{WB}=$ White Banks; $\mathrm{PI}=$ Pickles Reef; $\mathrm{u}, \mathrm{v}=$ crossshelf and alongshore components, respectively. All correlation coefficients listed are maximum values obtained within positive $6 \mathrm{~d}$ lag period and are significant at $95 \%$ confidence level unless denoted by ns (not significant). All coefficients listed are for lag of zero unless otherwise indicated by lag in days in parentheses (i.e. number in days that an environmental event preceded occurrence of larvae). Negative lags were disregarded, as this indicated that occurrence of larvae preceded an environmental event. Shaded boxes indicate what were considered meaningful correlations

\begin{tabular}{|lcccc|}
\hline Environmental parameters & FR 2002 & FR 2003 & WB 2002 & PI 2003 \\
\hline (a) & & & & \\
Maximum amplitude tides & $-0.25(4)$ & -0.50 & $-0.25(6)$ & $-0.50(3)$ \\
\% lunar illumination & -0.70 & -0.70 & -0.50 & -0.50 \\
Moonlit rising hours & -0.25 & -0.25 & $0.25(6)$ & -0.25 \\
Moonlit falling hours & -0.50 & -0.60 & -0.40 & -0.50 \\
Total moonlit hours & -0.60 & -0.50 & -0.40 & -0.50 \\
Dark rising hours & 0.25 & 0.25 & 0.40 & 0.25 \\
Dark falling hours & 0.50 & 0.50 & 0.50 & 0.50 \\
Total dark hours & 0.50 & 0.50 & 0.50 & 0.50 \\
Total rising hours & $\mathrm{ns}$ & $\mathrm{ns}$ & $0.25(4)$ & $\mathrm{ns}$ \\
Total falling hours & -0.25 & -0.25 & $0.40(6)$ & $0.25(2)$ \\
(b) & & & & \\
Total dark hours first half & $0.50(2)$ & $0.50(2)$ & 0.50 & $0.50(4)$ \\
Total dark hours second half & 0.30 & 0.30 & 0.30 & 0.40 \\
Dark falling hours first half & 0.50 & 0.45 & 0.50 & 0.50 \\
Dark falling hours second half & 0.30 & 0.30 & 0.25 & 0.30 \\
(c) & & \multicolumn{3}{c}{} \\
v (alongshore) wind & $0.25(5)$ & 0.25 & $\mathrm{~ns}$ & $0.25(0,4)$ \\
u (cross-shelf) wind & $0.25(4)$ & $-0.25(6)$ & -0.25 & $0.40(4)$ \\
v current (21 m) & $\mathrm{ns}$ & 0.25 & $\mathrm{~ns}$ & $-0.25(2)$ \\
u current (21 m) & $-0.25(6)$ & $\mathrm{ns}$ & -0.25 & $-0.25(2)$ \\
v current (4 m) & $\mathrm{ns}$ & 0.25 & $\mathrm{~ns}$ & 0.40 \\
u current (4 m) & $\mathrm{ns}$ & $\mathrm{ns}$ & $\mathrm{ns}$ & 0.25 \\
\hline
\end{tabular}



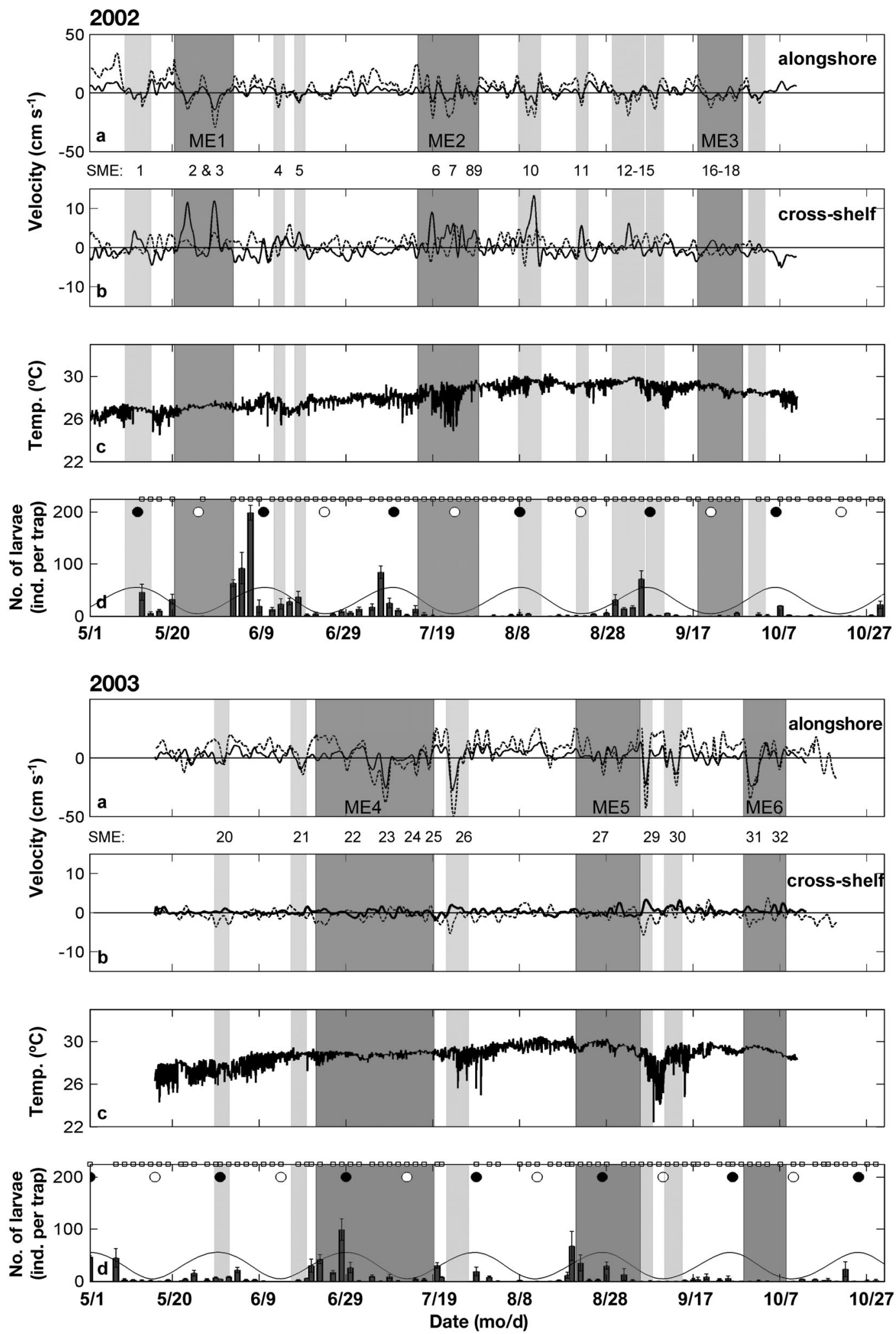

Fig. 6. Time series of $40 \mathrm{~h}$ low pass filtered (a) alongshore and (b) cross-shelf residual current velocity; (c) raw temperature; (d) average nightly observed settlement-stage larval supply at French Reef (bars) and expected larval supply based on lunar illumination (line) during 2002 and 2003. Continuous and dashed lines represent current velocities at 21 and $4 \mathrm{~m}$ depth, respectively. Dark gray bands indicate presence of mesoscale eddies (ME) and light gray bands sub-mesoscale eddies (SME). (O) Full moon, (๑) new moon, ( $\square$ ) nights sampled. Error bars represent SE 
Table 3. Mann-Whitney statistics for paired site comparisons between Pickles Reef and French Reef, and White Banks and French Reef. Sample size (n) was equal for each site in a comparison. Critical values of $U$ were not available for sample sizes $>20$ and a normal approximation of the $U$ statistic was calculated (Zar 1999). ${ }^{*}$ Significant at $\mathrm{p}<0.05$. $U_{\text {crit }}=$ the critical value of $U$ for a 2-tailed test at $\alpha=0.05 ; Z_{\text {crit }}=$ the critical value of $Z$ at $\alpha=0.05$

\begin{tabular}{|c|c|c|c|c|c|}
\hline Variable & $\mathrm{n}$ & $U$ & $U_{\text {crit }}$ & $Z$ & $Z_{\text {crit }}$ \\
\hline \multicolumn{6}{|l|}{ Pickles Reef vs. French Reef } \\
\hline $\begin{array}{l}\text { All settlement-stage fishes } 2003 \\
\text { (May-October) }\end{array}$ & 78 & 2778 & & 0.933 & 1.96 \\
\hline $\begin{array}{l}\text { Family richness } 2003 \\
\text { (May-October) }\end{array}$ & 78 & 2722 & & 1.132 & 1.96 \\
\hline $\begin{array}{l}\text { All settlement-stage fishes } 2003 \\
\text { (bimonthly, year-round) }\end{array}$ & 10 & 30 & 77 & & \\
\hline $\begin{array}{l}\text { Family richness } 2003 \\
\text { (bimonthly, year-round) }\end{array}$ & 10 & 26 & 77 & & \\
\hline \multicolumn{6}{|l|}{ White Banks vs. French Reef } \\
\hline $\begin{array}{l}\text { All settlement-stage fishes } 2002 \\
\text { (May-October) }\end{array}$ & 67 & 1537 & & $3.15^{*}$ & 1.96 \\
\hline $\begin{array}{l}\text { Family richness } 2002 \\
\text { (May-October) }\end{array}$ & 67 & 1190 & & $4.70^{*}$ & 1.96 \\
\hline $\begin{array}{l}\text { All settlement-stage fishes } 2002 \\
\text { (bimonthly, year-round) }\end{array}$ & 12 & 37 & 107 & & \\
\hline $\begin{array}{l}\text { Family richness } 2002 \\
\text { (bimonthly, year-round) }\end{array}$ & 12 & 45 & 107 & & \\
\hline
\end{tabular}

waters to become southwesterly in fall and winter months (Lee 1986). The supply of the post-larval spiny lobster Panulirus argus to the FK over 8 yr was correlated with these NE winds (Acosta et al. 1997). Lee \& Williams (1999) hypothesized that this seasonal shift coupled with enhanced onshore surface Ekman flow may act as a mechanism of larval retention and provide enhanced opportunity for fish larvae to settle on FK reefs. Peak larval supply to FR during the late winter and early spring may be the result of this seasonal environmental shift.

\section{Within-season patterns of larval supply}

Larval supply of most fishes in this study peaked between the third quarter moon/ minimum amplitude tides and new moon/ maximum amplitude tides. Synchronous supply of diverse fish larvae on a particular lunar or tidal phase could be the result of the timing of adult reproduction, passive

\section{Seasonal patterns of larval supply}

Peak spawning and subsequent recruitment for most reef fishes in the Caribbean is thought to occur in the late winter (dry season) to early spring and late spring to early summer, respectively (e.g. Munro et al. 1973, Robertson 1990, Hunt von Herbing \& Hunte 1991, Tupper \& Hunte 1994). In the present study, the larval supply of many families of reef fish was generally consistent with this pattern and peaked during the summer months; however, several others peaked during the late winter-early spring months. With the exception of certain serranids and the pinfish Lagodon rhomboides, which have a truncated spawning season in the winter months (resulting in larvae appearing only in the late winter-early spring), most of the other families spawn throughout the year (Thresher 1984, Zieske 1989). Observed seasonal patterns of supply in these families could be the result of earlier peaks in spawning activity and/or differential survival or transport of eggs and larvae due to seasonal environmental shifts. Several recent studies have highlighted the importance of such shifts in wind, water temperature, and climate to the survival and growth of larvae as well as subsequent recruitment magnitude of reef fishes (Robertson et al. 1999, Bergenius et al. 2005, Sponaugle et al. 2006). In the FK, a shift in the prevailing winds from weak SE winds in the summer to strong NE winds in the fall and winter reduces FC transport and shifts mean flows over the outer shelf and nearshore delivery by currents, or active larval behavior. Within the family Pomacentridae, temporal patterns of larval supply and settlement have been linked to similar patterns in spawning (Robertson et al. 1988, Meekan et al. 1993, Danilowicz 1997), but there is also evidence of significant decoupling of these 2 processes (Robertson et al. 1993, McIlwain 2002). Several other reef fishes have highly variable pelagic larval durations (Victor 1986a, Sponaugle \& Cowen 1994, McCormick 1999), further decoupling patterns of supply and settlement from patterns of reproduction. Because such a diverse group of fish larvae shared a similar pattern of occurrence in this study, it is unlikely that observed larval supply patterns were due to patterns of reproduction.

Settling larval reef fish are thought to avoid shallow reef areas during the day and bright phases of the moon to reduce mortality by visual predators (Johannes 1978). The nights between the third quarter and new moon, when the supply of most larval fish taxa peaked, are periods of increasing relative darkness. This, coupled with the strong correlation between larval supply and lunar illumination in both years and scarcity or absence of all larvae from catches around full moons, is consistent with the concept of larval fish avoiding the water column over the reef during lunar phases and times of the night when there is considerable lunar illumination. Overall lunar illumination between the third quarter and new moon is similar to that between the new and first quarter moon. However, the first half of the night lacks any lunar illumination between the third quarter and new moon, 
while between the new and first quarter moon is a period of increasing lunar illumination. Previous observations that larval fish at Barbados arrive at the reef primarily during the first half of the night (S. Sponaugle unpubl. data), as well as the finding that correlations between half-nightly hours of proximate environmental processes and larval supply tended to be stronger during the first half of the night, further support lunar illumination as the major settlement cue for larval fishes.

If the relative brightness of the night was the only important cue, however, most supply would occur during new moon periods. This was the case for haemulids, apogonids, scorpaenids (Type A), and scarids (Sparisoma spp.); thus lunar illumination may be the overwhelmingly dominant cue for settlement behavior in these larvae. Larval supply cued entirely by tidal amplitude cycles should peak twice a month, on the minimum or maximum amplitude tides. The supply of the pomacentrid Stegastes partitus exhibited such a pattern, peaking on the quarter moons and minimum amplitude tides, indicating that the tidal amplitude cycle may be the most important settlement cue for this species. For most larvae, however, lunar illumination was a dominant, although probably not singular, factor in within-season patterns of larval supply. Supply occurred primarily on the darkest nights with the smallest amplitude tides and maximum hours of nocturnal falling tides. Reyns \& Sponaugle (1999) found similar patterns in the supply of postlarval brachyuran crabs to Barbados and hypothesized that chemical compounds from the reef environment may be carried offshore by falling (ebbing) nocturnal tides and act as settlement cues that larvae can track back to the reef.

\section{FC frontal eddies and episodic within-season pattern of larval supply}

Although larval fish supply to the FK was largely cyclic and related to lunar and tidal cycles, some variability in the magnitude of supply remained unexplained. Wind had little effect on flow during the nearcontinuous sampling periods in this study, but may influence currents more significantly in the study area during the fall and winter when they shift and intensify, blowing from the E and NE. Supply of larvae to the reef was also unrelated to the occurrence of internal tidal bores, although it should be noted that the light traps were designed to sample late-stage fish larvae near the surface and would have undersampled larvae that might have been entrained in internal tidal bores near or along the bottom. Instead, the remaining variability in larval supply may be due to planktonic patchiness or encounter with episodic oceanographic features such as passing frontal eddies of the FC.
Because MEs have been previously implicated in delivering larvae to FK reefs, we examined the potential impact of these features in greater detail.

Of the 4 larger than expected larval pulses to FR (based on lunar illumination), 3 occurred during the presence of mesoscale frontal eddies; 2 of these pulses occurred at the beginning of MEs (28 June and 20 August 2003), and 1 at the end (3 to 7 June 2002), when the leading and lagging meander crests of these eddies were approaching the study area. Meander crests are located upstream and downstream of eddies, which exist in the meander troughs displaced offshore. A strong front exists between these crests and associated eddies where larvae may be concentrated, especially in the lagging shoreward side of an eddy where downstream flow in the meander crest converges with upstream flow inside the eddy (Sponaugle et al. 2005).

The largest larval supply event of the entire study occurred on 7 June 2002, 4 d after the passage of ME 1. Although only 1 night was sampled during the nearshore presence of ME 1, no larval fishes were collected. This is most likely to have been due to the passage of this eddy by the upper FK during the period around the full moon. It is possible that this eddy delivered fish larvae to the study area, but these larvae delayed settlement until several days later, closer to optimal settlement times based on lunar and tidal cues. MEs 2 and 3, which were not associated with enhanced larval supply, also occurred within several days of the full moon/maximum tidal amplitude, indicating that timing with respect to lunar and tidal cues likely plays an important role in determining whether eddies successfully deliver fish larvae to reefs.

Lower than expected larval supply occurred for several weeks following the passage of MEs 2, 3, and 6 . MEs 3 and 6 occurred during late September to early October in 2002 and 2003, respectively. Scarce larval fish supply also occurred during a late September ME at FR in 2001 (Sponaugle et al. 2005), and this trend may be related to reproductive seasonality. However, lower than expected larval supply for several weeks following ME 2 in 2002 indicates that the passage of these features may also have the potential disrupt the supply of fish larvae. Similar results were noteed during a study in Barbados, where the passage of some North Brazil Current rings enhanced retention and settlement of fish larvae while the passage of others advected larvae away from the island, resulting in settlement failure (Cowen et al. 2003).

In general, the effects of frontal eddies on the delivery of larvae are not consistent in space or time. Sponaugle et al. (2005) identified several criteria that must be met for eddies to successfully enhance larval supply: (1) larvae and/or eggs must be present (successful spawning) at the time of an eddy passage to be 
successfully entrained, (2) a mechanism must be present for larvae and/or eggs to enter the eddy, (3) upon delivery back to the reef, entrained larvae must be of a sufficient size and age (i.e. competent) to settle, (4) the environment inside the eddy must be favorable for growth and survival of the larvae (i.e. an abundance of food and scarcity of predators), and (5) the eddy must pass over suitable settlement habitat. To this list, we add that the passage of an eddy must be coincident with the appropriate lunar and tidal cues in order to facilitate successful supply and subsequent settlement of entrained fishes to the reef.

\section{Spatial patterns of larval supply}

While the ubiquitous nature of the lunar and tidal amplitude cycles led to similar patterns of larval supply to all sites, significant cross-shelf differences in the magnitude of larval supply occurred between FR and WB, with FR receiving approximately 6 times more larvae during the 6 mo near-continuous sampling period. Similar cross-shelf differences in larval supply and recruitment have been found in Caribbean Panama (Victor 1986b, Wilson 2001) and the Great Barrier Reef (Milicich 1994, Milicich \& Doherty 1994). These were attributed, at least in part, to depletion of larvae originating from open water as they crossed the reef margin and settled to the fringing reef or the first suitable habitat encountered. In the upper FK, larval fishes delivered by the FC and its associated frontal eddies would encounter the bank reef well before physical transport or active swimming would bring them to more inshore reefs such as WB. The finding that larval sphyraenids, gerreids, and lutjanids Lutjanus griseus, which settle to nearshore seagrass and mangrove habitats, also follow this pattern suggests that larvae passing over the bank reef may be lost not only to settlement, but possibly also to predation. Additionally, currents inside Hawk Channel are variable, mostly influenced by tide and wind, and are much weaker than those on the outer shelf (Lee 1986, Pitts 1994). Weaker, more variable currents may have also contributed to the observed difference in larval supply between inshore (WB) and offshore (FR) reefs, as traps over WB presumably sampled less water. An additional marked difference in larval supply between these 2 reefs was an increase in larval supply at WB during the fall and winter, when larval supply at FR was scarce. In fact, $45 \%$ of the 751 settlement-stage larvae captured at WB during 81 total sampling nights were captured on only 11 sample nights during the late fall, winter, and early spring of 2002 to 2003.

Spatial differences in larval supply have important consequences for the structure and dynamics of adult reef fish assemblages as well as management and conservation of fish stocks on these reefs. For example, the more diverse and higher magnitude larval supply to bank reefs such as FR and PI relative to inshore patch reefs such as WB suggests that inshore reefs may be more susceptible to and recover more slowly from negative impacts such as overfishing. Further, spatial and temporal scales of supply intersect such that replenishment to some sites is more important during different times of the year. In the FK, higher supply of reef fishes to inshore habitats in the fall as opposed to spring and summer may result in higher settlement variability as fall oceanographic variability (e.g. hurricanes) may frequently disrupt successful larval delivery. The supply of fish larvae to the reefs of the upper FK is largely lunar-cyclic, with variability due to other factors such as episodic oceanographic processes and cross-shelf position superimposed onto this pattern. Although all methods of larval fish capture have shortcomings and light traps only collect phototaxic larvae, these patterns of larval supply were exhibited by a diversity of larval fishes. These predictable and episodic patterns of larval supply provide a framework upon which early post-settlement processes can operate to influence overall patterns of population replenishment.

Acknowledgements. The biological component of the research was supported by a National Science Foundation grant (OCE 9986359) to S.S. and an International Light Tackle Tournament Association grant to E.D. Additional support for biological sampling as well as for collection of current meter and hydrographic data was obtained from the National Center for Caribbean Coral Reef Research through Environmental Protection Agency Grant (R82802001). Nearshore light trap sampling was conducted under permit 00S-524 from the Florida Fish and Wildlife Conservation Commission and permit FKNMS-2001-004 from the Florida Keys National Marine Sanctuary. Current meters were deployed under permit FKNMS-2000-018. Ocean color images were provided by F. Müller-Karger of the University of South Florida's Institute for Marine Remote Sensing. Assistance in light trap deployment and collection was provided by J. Fortuna, J. Llopiz, S. Cappell, K. Huebert, S. Luthy, K. Grorud-Colvert, D. Pinkard, K. Denit, M. Paddack, and L. Buhrmaster. Both J. Llopiz and S. Cappell also assisted with sample sorting, and C. Paris and D. Richardson lent expert assistance in larval fish identification. We thank W. Richards for providing preliminary chapters of his new book on larval identification. K. Grorud-Colvert and 3 anonymous reviewers provided helpful comments on earlier drafts of this manuscript.

\section{LITERATURE CITED}

Acosta CA, Matthews TR, Butler MJ (1997) Temporal patterns and transport processes in recruitment of spiny lobster (Panulirus argus) postlarvae to south Florida. Mar Biol 129:79-85

Batschelet E (1981) Circular statistics in biology. Academic Press, New York 
Bergenius MAJ, McCormick MI, Meekan MG, Robertson DR (2005) Environmental influences on larval duration, growth and magnitude of settlement of a coral reef fish. Mar Biol 147:291-300

Choat JH, Doherty PJ, Kerrigan BA, Leis JM (1993) A comparison of towed nets, purse seine, and light-aggregation devices for sampling larvae and pelagic juveniles of coral reef fishes. Fish Bull US 91:1155-1160

Cowen RK (2002) Larval dispersal and retention and consequences for population connectivity. In: Sale PF (ed) Coral reef fishes: dynamics and diversity in a complex ecosystem. Academic Press, New York, p 149-170

Cowen RK, Sponaugle S, Paris CB, Fortuna JL, Lwiza KMM, Dorsey S (2003) Impact of North Brazil Current rings on local circulation and coral reef fish recruitment to Barbados, West Indies. Elsev Ocean Ser 68:443-462

Criales MM, Lee TN (1995) Larval distribution and transport of penaeoid shrimps during the presence of the Tortugas Gyre in May-June 1991. Fish Bull US 93:471-482

Danilowicz BS (1997) A potential mechanism for episodic recruitment of a coral reef fish. Ecology 78:1415-1423

Doherty PJ (1987) Light-traps: selective but useful devices for quantifying the distributions and abundances of larval fishes. Bull Mar Sci 41:423-431

Doherty PJ (1991) Spatial and temporal patterns in recruitment. In: Sale PF (ed) The ecology of fishes on coral reefs. Academic Press, New York, p 261-293

Dorsey SE (2000) The role of oceanographic and seasonal environmental processes in the early life history of two coral reef fish (Pomacentridae). PhD dissertation, State University of New York at Stony Brook

Dufour V, Galzin R (1993) Colonization patterns of reef fish larvae to the lagoon at Moorea Island, French Polynesia. Mar Ecol Prog Ser 102:143-152

Fratantoni PS, Lee TN, Podesta GP, Muller-Karger F (1998) The influence of loop current perturbations on the formation and evolution of Tortugas eddies in the southern Straits of Florida. J Geophys Res 103:759-779

Hunt von Herbing I, Hunte W (1991) Spawning and recruitment of the bluehead wrasse Thalassoma bifasciatum in Barbados, West Indies. Mar Ecol Prog Ser 72:49-58

Johannes RE (1978) Reproductive strategies of coastal marine fishes in the tropics. Environ Biol Fish 3:65-84

Kingsford M, Finn M (1997) The influence of phase of the moon and physical processes on the input of presettlement fishes to coral reefs. J Fish Biol 51:176-205

Lee TN (1975) Florida Current spin-off eddies. Deep-Sea Res 22:753-765

Lee TN (1986) Coastal circulation in the Key Largo coral reef marine sanctuary. In: van de Kreeke J (ed) Physics of shallow estuaries and bays, Vol 16. Springer-Verlag, New York, p 178-198

Lee TN, Williams E (1999) Mean distribution and seasonal variability of coastal currents and temperature in the Florida Keys with implications for larval recruitment. Bull Mar Sci 64:35-56

Lee TN, Rooth C, Williams E, McGowan M, Szmant AF, Clarke ME (1992) Influence of Florida Current, gyres and wind-driven circulation on transport of larvae and recruitment in the Florida Keys coral reefs. Cont Shelf Res 12: 971-1002

Lee TN, Clarke ME, Williams E, Szmant AF, Berger T (1994) Evolution of the Tortugas Gyre and its influence on recruitment in the Florida Keys. Bull Mar Sci 54:621-646

Lee TN, Leaman K, Williams E, Berger T, Atkinson L (1995) Florida Current meanders and gyre formation in the southern Straits of Florida. J Geophys Res 100:8607-8620
Leichter JJ, Wing SR, Miller SL, Denny MW (1996) Pulsed delivery of subthermocline water to Conch Reef (Florida Keys) by internal tidal bores. Limnol Oceanogr 41: 1490-1501

Leichter JJ, Shellenbarger G, Genovese SJ, Wing SR (1998) Breaking internal waves on a Florida (USA) coral reef: a plankton pump at work? Mar Ecol Prog Ser 166:83-97

Leis JM, Carson-Ewart BM (1999) In situ swimming and settlement behaviour of larvae of an Indo-Pacific coral-reef fish, the coral trout Plectropomus leopardus (Pisces: Serranidae). Mar Biol 134:51-64

Limouzy-Paris CB, Graber HC, Jones DL, Roepke AW, Richards WJ (1997) Translocation of larval coral reef fishes via sub-mesoscale spin-off eddies from the Florida Current. Bull Mar Sci 60:966-983

Lozano S, Zapata FA (2003) Short-term temporal patterns of early recruitment of coral reef fishes in the tropical eastern Pacific. Mar Biol 142:399-409

McCormick MI (1999) Delayed metamorphosis of a tropical reef fish (Acanthurus triostegus): a field experiment. Mar Ecol Prog Ser 176:25-38

McIlwain JL (2002) Link between reproductive output and larval supply of a common damselfish species, with evidence of replenishment from outside the local population. Mar Ecol Prog Ser 236:219-232

Meekan MG, Milicich MJ, Doherty PJ (1993) Larval production drives temporal patterns of larval supply and recruitment of a coral reef damselfish. Mar Ecol Prog Ser 93:217-225

Meekan MG, Doherty PJ, White L Jr (2000) Recapture experiments show the low sampling efficiency of light traps. Bull Mar Sci 67:875-885

Meekan MG, Wilson SG, Halford A, Retzel A (2001) A comparison of catches of fishes and invertebrates by two light trap designs, in tropical NW Australia. Mar Biol 139: 373-381

Milicich MJ (1994) Dynamic coupling of reef fish replenishment and oceanographic processes. Mar Ecol Prog Ser 110:135-144

Milicich MJ, Doherty PJ (1994) Larval supply of coral reef fish populations: magnitude and synchrony of replenishment to Lizard Island, Great Barrier Reef. Mar Ecol Prog Ser 110:121-134

Morgan SG, Christy JH (1994) Plasticity, constraint, and optimality in reproductive timing. Ecology 75:2185-2203

Munro JL, Gaut VC, Thompson R, Reeson PH (1973) The spawning seasons of Caribbean reef fishes. J Fish Biol 5:69-84

Pitts PA (1994) An investigation of near-bottom flow patterns along and across Hawk Channel, Florida Keys. Bull Mar Sci 54:610-620

Reyns N, Sponaugle S (1999) Patterns and processes of brachyuran crab settlement to Caribbean coral reefs. Mar Ecol Prog Ser 185:155-170

Richards WJ (ed) (2006) Early stages of Atlantic fishes: An identification guide for the Western Central North Atlantic, Vol I \& II. Taylor \& Francis, New York

Roberts J, Roberts TD (1978) Use of the Butterworth low-pass filter for oceanographic data. J Geophys Res 83:5510-5514

Robertson DR (1990) Differences in the seasonalities of spawning and recruitment of some small neotropical reef fishes. J Exp Mar Biol Ecol 144:49-62

Robertson DR (1992) Patterns of lunar settlement and early recruitment in Caribbean reef fishes at Panama. Mar Biol 114:527-537

Robertson DR, Kaufmann KW (1998) Assessing early recruitment dynamics and its demographic consequences among 
tropical reef fishes: accommodating variation in recruitment seasonality and longevity. Aust J Ecol 23:226-233

Robertson DR, Green DG, Victor BC (1988) Temporal coupling of production and recruitment of larvae of a Caribbean reef fish. Ecology 69:370-381

Robertson DR, Schober UM, Brawn JD (1993) Comparative variation in spawning output and juvenile recruitment of some Caribbean reef fishes. Mar Ecol Prog Ser 94:105-113

Robertson DR, Swearer SE, Kaufmann K, Brothers EB (1999) Settlement vs. environmental dynamics in a pelagicspawning reef fish at Caribbean Panama. Ecol Monogr 69:195-218

Sponaugle S, Cowen RK (1994) Larval durations and recruitment patterns of two Caribbean gobies (Gobiidae): Contrasting early-life histories in demersal spawners. Mar Biol 120:133-143

Sponaugle S, Cowen RK (1996a) Larval supply and patterns of recruitment for two Caribbean reef fishes, Stegastes partitus and Acanthurus bahianus. Mar Freshw Res 47: 433-447

Sponaugle S, Cowen RK (1996b) Nearshore patterns of coral reef fish larval supply to Barbados, West Indies. Mar Ecol Prog Ser 133:13-28

Sponaugle S, Cowen RK (1997) Early life history traits and recruitment patterns of Caribbean wrasses (Labridae). Ecol Monogr 67:177-202

Sponaugle S, Fortuna J, Grorud K, Lee T (2003) Dynamics of larval fish assemblages over a shallow coral reef in the Florida Keys. Mar Biol 143:175-189

Sponaugle S, Lee T, Kourafalou V, Pinkard D (2005) Florida current frontal eddies and the settlement of coral reef fishes. Limnol Oceanogr 50:1033-1048

Sponaugle S, Grorud-Colvert K, Pinkard D (2006) Tem-

Editorial responsibility: Otto Kinne (Editor-in-Chief),

Oldendorf/Luhe, Germany perature-mediated variation in early life history traits and recruitment success of the coral reef fish Thalassoma bifasciatum in the Florida Keys. Mar Ecol Prog Ser 308: $1-15$

Thorrold SR, Shenker JM, Maddox ED, Mojica R, Wishinski E (1994) Larval supply of shorefishes to nursery habitats around Lee Stocking Island, Bahamas. 2. Lunar and oceanographic influences. Mar Biol 118:567-578

Thresher RE (1984) Reproduction in reef fishes. TFH Publications, Neptune City, NJ

Tupper M, Hunte W (1994) Recruitment dynamics of coral reef fishes in Barbados. Mar Ecol Prog Ser 108:225-235

Valles H, Sponaugle S, Oxenford HA (2001) Larval supply to a marine reserve and adjacent fished area in the Soufriere marine management area, St Lucia, West Indies. J Fish Biol 59:152-177

Victor BC (1986a) Delayed metamorphosis with reduced larval growth in a coral reef fish (Thalassoma bifasciatum). Can J Fish Aquat Sci 43:1208-1213

Victor BC (1986b) Larval settlement and juvenile mortality in a recruitment-limited coral reef fish population. Ecol Monogr 56:145-160

Wilson DT (2001) Patterns of replenishment of coral-reef fishes in the nearshore waters of the San Blas Archipelago, Caribbean Panama. Mar Biol 139:735-753

Yeung C, Lee TN (2002) Larval transport and retention of the spiny lobster, Panulirus argus, in the coastal zone of the Florida Keys, USA. Fish Oceanogr 11:286-309

Zar JH (1999) Biostatistical analysis, 4th edn. Prentice Hall, Upper Saddle River, NJ

Zieske GG (1989) Redescription of larvae of the pinfish, Lagodon rhomboides (Linnaeus) (Pisces, Sparidae). Contrib Mar Sci 31:51-59

Submitted: February 27, 2006; Accepted: June 6, 2006

Proofs received from author(s): February 6, 2007 